\title{
UNIFORMITY VERSUS FLEXIBILITY: A REVIEW OF THE RHETORIC
}

\author{
Thomas F. KeLleR*
}

How will the historian of accounting, looking back at you and me from A.D. two thousand and something, describe us?

I suggest he might do worse than interpret the present state of accounting as a clash between two ways of thought-as yet one more example of the universal conflict between the man who wants to tug at the brake and the man who wants to step on the accelerator.

-Baxter, Accounting Principles: The Conflict in Current Theory, 128 AcCountant 699 (1953).

The controversy among certified public accountants from Maine to California over "uniformity" versus "flexibility" has probably attracted more attention to the practice of public accounting than any other debate since the enactment of the Securities Act of $1933^{1}$ and the Securities Exchange Act of $1934 .^{2}$ What lies behind this debate? Why are so many people involved? Why is the argument taken so seriously? At stake are matters no less critical than the reliability and comparability of published corporate financial statements accompanied by a standard CPA's certificate, which generally reads substantially as follows:

In our opinion, the accompanying balance sheet and statement of income (and other statements included in the report) present fairly the financial position of XYZ Company at December $3 x, 19-$, and the results of its operations for the year then ended, in conformity with generally accepted accounting principles applied on a basis consistent with that of the preceding year.

The importance of accurate and useful financial information in a dynamic economy can hardly be overemphasized. If, as has been claimed, the accuracy and utility of financial reporting are in doubt, the seriousness of the debate for the whole accounting profession is great.

The charge of those supporting "uniformity" is that there is no authoritative and generally recognized body of accounting principles to which the investor or the public can look when examining financial statements. Thus the confidence of the investor or other outsider must rest largely on his faith in the accountant's integrity, and the advocates of uniformity claim that this faith has been shaken. The

*A.B. 1953, Duke University; M.B.A. I957, Ph.D. I960, University of Michigan. Associate Professor of Accounting, Duke University; Certified Public Accountant, North Carolina; member of N.C. Association of CPAs and the American Institute of CPAs. Author, Accounting For Corporate Income Taxes (I96I); [with W. B. Meigs \& C. E. Johnson] Intermediate Accounting (I963); [with S. A. Zeff] Financial Accounting Theory: Issues and Controversies (I964). Contributor to accounting periodicals.

${ }_{4} 8$ Stat. 74 , as amended, 15 U.S.C. $\$ \$ 77 \mathrm{a}-\mathrm{aa}(1964)$.

${ }^{2} 48$ Stat. $88 \mathrm{I}$, as amended, 15 U.S.C. $\$ \$ 78 \mathrm{a}-\mathrm{hh}$ (1964). 
most outspoken critics of current practice claim that financial reports at the present time do not provide adequate information presented in such a way as to allow the potential investor to make an intelligent choice among alternative investments. In short, the charge is that comparability between companies is lacking and that accountants are to blame. Those who support "flexibility" in general argue that meaningful comparability of financial data reflecting the affairs of diverse business organizations is a utopian goal and that, in any case, it cannot be achieved by the adoption of firm rules that do not take adequate account of differing factual situations.

Charges and Pressures for Action

Charges of the accountant's neglect of outsiders' interests and of his lack of independence from corporate management have come from many quarters. Steven Anreder, writing for Barron's, ${ }^{3}$ cites specific examples of accounting practices that are not considered to be consistent with generally accepted accounting principles. Among these are Chock Full O'Nuts Corporation's capitalization of outlays for advertising, promotion, and research and development and Colgate-Palmolive's election to discontinue the amortization of good will. Anreder is, nevertheless, quite charitable in his remarks. He observes that

the [Chock Full O'Nuts] incident serves as a timely reminder of something few investors bother to consider: that accounting is a very fluid practice. Accounting varies from industry to industry. In fact, even among companies in the same field, practices are so diverse as to make comparisons of earnings less than meaningful. ${ }^{4}$

In the same section of his article Mr. Anreder states,

Without question stockholders today are better informed than they used to be.... Gone are the days when a company could report what it wanted, whenever it cared to, or even refuse to report at all. Owing to enactment of the securities laws, more stringent regulation by stock exchanges and .... a more responsible approach by management, the quality of financial data presented to U.S. investors is unrivaled anywhere in the world. 5

In a news article published in January 1963 , Business Week cited the 1957 annual report of Swift \& Company as evidence of lack of consistency:

Operating entirely within the framework of generally accepted accounting principles, Swift cut contributions to its pension plan to $\$$ I.r million from $\$ 13.6$ million the year before. The difference of $\$ 12.5$ million amounted to over $90 \%$ of the net income that Swift reported for 1957. Thus, the company was able to keep its earn-

\footnotetext{
${ }^{3}$ Anreder, Pitfalls for the Unwary, Barron's, Dec. 24, 1962, p. 3.

${ }^{4}$ Ibid.

${ }^{5}$ Ibid.
} 
ings on an even keel, despite the "unfavorable margins" that prevailed in the packing industry that year. ${ }^{6}$

Situations like these are embarrassing to accountants for the reason stated by Thomas G. Higgins of Arthur Young \& Co., Swift's auditor, to the Business Week reporter: "There was nothing we could do-we had no firm guidelines to follow."

Professor Robert N. Anthony cites a different type of situation: "General Motors and Standard Oil of New Jersey each recently sold its half ownership in Ethyl Corporation at a book gain of many millions of dollars. GM reported its fifty per cent of the gain as part of its net income for the year. Standard Oil left net income unaffected, crediting its fifty per cent directly to surplus." Professor Anthony makes no judgment-he is merely pointing out the lack of accepted accounting principles that could be used to guide accountants in such situations.

In the above cited cases there is no charge that the published financial statements are in error. In the Barron's article, the reporter merely implies that unusual procedures were employed; in the particular case the procedure used may have been appropriate. But how can these statements be compared with similar enterprises that follow a procedure of classifying outlays like these as period expenses? Likewise, in the Swift \& Co. case, the writer calls attention to a change in the method used to determine the annual pension cost, but this is not to say that the I3.6 million dollar figure was correct and the I.I million dollar figure erroneous. Nevertheless, there is no escaping the fact that a change in accounting method resulted in incomparable operating results for two consecutive years. Finally, Professor Anthony has pointed out how altogether different procedures were applied to a common situation. Which procedure was correct? There are opinions to support each, but some accountants would contend that there is no authority by which this situation can be finally resolved. Undoubtedly the accountants on either side of this question felt that their position was the sounder.

The recital of situations such as those discussed here has greatly aided the cause of the advocates of uniformity. On the surface at least there appears to be a need for more uniform practice. But this need may be more apparent than real. Whether this is the case is a major issue yet to be resolved by the accounting profession, and it may be the issue at the heart of the current controversy.

By calling attention to situations such as those cited above, the critics are in some sense issuing a mandate to the Securities and Exchange Commission to investigate the adequacy of the information provided to investors. If the information is found, or believed, to be inadequate, then the Commission might choose to exercise powers over accounting practices granted it in the Securities Act of $1933 .^{\circ}$ This act provides

\footnotetext{
- A Matter of Principle Splits CPAs, Business Week, Jan. 26, 1963, p. 50 , at 56 .

${ }^{2}$ Ibid.

${ }^{3}$ Anthony, Showdown on Accounting Principles, Harv. Bus. Rev., May-June I963, p. 99, at ror.

- $\S$ I9(a), 48 Stat. 85, as amended, I5 U.S.C. \$ $77 \mathrm{~s}$ (a) (I964).
} 
ample authority for the Commission to extend its regulation of the practice of accountancy by prescribing detailed rules and regulations for the presentation of financial information.

Accountants would like to avoid further regulation by the SEC, and they would like to have the confidence of the security analyst and the investor. Of almost equal importance is the fact that there have been an increasing number of lawsuits brought against accountants by investors who believe they have been damaged by relying on financial information which, in spite of the expressed opinion of the CPA, was not fairly presented. ${ }^{10}$ For these and probably other reasons accountants are actively engaged in the debate regarding the standards of accounting practice.

II

\section{Histortcal Background of the Debate}

\section{A. Early Views}

In 1927, in discussing the practice of accounting, Professor Henry R. Hatfield mentioned that one of the achievements of accounting

is the effort to introduce some unity into accounting theory instead of regarding its phenomena as diverse. For long it was generally considered that the investment of capital was in marked opposition to the payment of an expense. This view was crystallized in the phrase "capital expenditure or charge against revenue." It assumed that these two were radically different in nature, and one must never be confounded with the other. Today one sees a continuous gradation, land, building, machinery, raw material, expense of labor-each one of a series, each differing only as to length of the service which it renders, each paid for with the view of getting all possible use out of it in the productive process. The development of this point is, I believe, a real achievement in accounting theory-one not dreamt of in earlier centuries. ${ }^{11}$

Later in the same piece, Hatfield remarked that "accounting . . needs something more than a definite nomenclature. It needs above all else the formulation of sound theories, which can be crystallized into clear terminology."12

J. M. B. Hoxsey of the Committee on Stock List of the New York Stock Exchange, spoke in $193^{\circ}$ of stockholders' needs for more information supplied in a more understandable form. He discussed the problems that were likely to arise and the areas of greatest concern, stating that "the exchange is interested in the accounts of companies as a source of reliable information for those who deal in stocks. It is not sufficient for the stock exchange that the accounts should be in conformity with law or even that they should be conservative; the stock exchange desires that they should be fully and fairly informative."13

In 1932 George O. May, in a letter to M. C. Rorty, an official of the Stock Ex.

\footnotetext{
${ }^{10}$ Editorial, The Specter of Auditors' Liability, J. Accountancy, Sept. r965, p. 33.

${ }^{11}$ Hatfield, What Is the Matter With Accounting?, 44 J. Accountancy 267, 270 (I927).

${ }^{12}$ Id. at 272.

${ }^{13}$ Hoxsey, Accounting for Investors, 50 J. Accountancy 25I, 253 (1930).
} 
change, concerning the limitations of legislating accounting rules, advanced the idea that

legislative provisions cannot be very effective-all that they can do is to establish a minimum standard which can be enforced universally without injustice.

You and I agree that industrial activity does not lend itself to uniform accounting. ... A Accounts must at best be conventional, and in attempting to attribute profits to short periods of time we are doing violence to the facts. The fundamental distinction between capital and revenue which lies at the root of all profit accounting is ultimately only a question of degree.

....

My idea would be that every corporation should adopt a method of accounting described in considerable detail. This method should be certified by its auditors as being in accordance with reasonable standards of business practice, and should be freely disclosed. The officers should then be guilty of falsification of accounts if they knowingly put forward any accounts not in conformity with the methods of accounting so adopted, and the auditors would be required to certify that the accounts were prepared in accordance with the corporation's official method....

The trouble with an "official" system of accounting is, that while it is possible to lay down broad principles, wide variations are possible within the limits of such principles, and which variation should be adopted is a question on which one cannot rightly be dogmatic. ${ }^{14}$

The Committee on Stock List of the Stock Exchange, following discussions with members of the American Institute of Accountants (AIA), recommended, and the Stock Exchange and the AIA agreed, that the Exchange should attempt to achieve

universal . . . acceptance by listed corporations of certain broad principles of accounting which have won fairly general acceptance, and within the limits of such broad principles to make no attempt to restrict the right of corporations to select detailed methods of accounting deemed by them to be best adapted to the requirements of their business .... ${ }^{15}$

The correspondence between the Stock Exchange and the AIA was filled with questions of terminology. The terms practices, principles, conventions, and rules were used almost interchangeably. Mr. May quotes one exchange of letters that illustrates the terminological confusion. The Stock Exchange posed six questions, the last of which was this: "Whether such system in their opinion conforms to accepted accounting practices, and particularly whether it is in any respect inconsistent with any of the principles set forth in the statement attached hereto."16 The accounting firms responded, "Your sixth question, apart from the specific reference to the principles enumerated, aims, we assume, to insure that companies are following accounting practices which have substantial authority back of them."17

\footnotetext{
${ }^{14}$ Memoirs and Accounting Thought of George O. May 6I-62 (Grady ed. 1962).

${ }^{15}$ Id. at 68.

${ }^{10}$ Id. at 74 . (Emphasis added by May.)

${ }^{17}$ Ibid.
} 


\section{B. Institutional Efforts}

Accounting Research Bulletin No. $\mathrm{I}^{18}$ was issued by the AIA in September I939. It set forth the conditions under which the Committee on Accounting Procedure intended to operate. As a matter of policy the Committee decided not to attempt an over-all coordinated statement of generally accepted accounting principles but rather to deal with particular questions or subjects as they seemed to require consideration.10 In Bulletin No. $x$, the Committee noted the change in the social system that permitted widespread ownership of securities and short-term holdings. In speaking of this change, the Bulletin stated,

This evolution has also led to a demand for a larger degree of uniformity in accounting. Uniformity has usually connoted similar treatment of the same item occurring in many cases, in which sense it runs the risk of concealing important differences among cases. Another sense of the word would require that different authorities working independently on the same case should reach the same conclusions. Although uniformity is a worthwhile goal, it should not be pursued to the exclusion of other benefits. Changes of emphasis and objective as well as changes in conditions under which business operates have led, and doubtless will continue to lead, to the adoption of new accounting procedures. Consequently diversity of practice may continue as new practices are adopted before old ones are completely discarded.

....

The principal objective of the committee has been to narrow areas of difference and inconsistency in accounting practices, and to further the development and recognition of generally accepted accounting principles, through the issuance of opinions and recommendations that would serve as criteria for determining the suitability of accounting practices reflected in financial statements and representations of commercial and industrial companies. ${ }^{20}$

Twenty years later the American Institute of Certified Public Accountants (AICPA), the successor to the AIA, modified its approach to the development of accounting principles. In September r958, the Special Committee on Research Program recommended an extensive revision of the procedures by which the Institute develops accounting guidelines. The Committee stated,

The general purpose of the Institute in the field of financial accounting should be to advance the written expression of what constitutes generally accepted accounting principles, for the guidance of its members and of others. This means something more than a survey of existing practice. It means continuing effort to determine appropriate practice and to narrow the areas of difference and inconsistency in

\footnotetext{
${ }^{18}$ Parts of this bulletin were incorporated into the Introduction, Comartres on Accountung ProCEDURE, AICPA, Restatement and Revision of Accounting Research Bulietins (Accounting Research Bull. No. 43, I953).

19 Comattee on Accounting Procedure, AiCPA, Final Report (I959), reprinted in part in J. Accountancy, Nov. I959, pp. 70-71.

${ }^{20}$ Committee on Accounting Procedure, AicPA, Restatement and Revision of Accountino ReseARCH Bulletins 7-8 (Accounting Research Bull. No. 43, 1953).
} 
practice. In accomplishing this, reliance should be placed on persuasion rather than on compulsion. The Institute, however, can, and it should, take definite steps to lead in the thinking on unsettled and controversial issues.

The broad problem of financial accounting should be visualized as requiring attention at four levels: first, postulates; second, principles; third, rules or other guides for the application of principles in specific situations; and fourth, research. ${ }^{21}$

The Accounting Principles Board (APB) was to be the official body of the Institute with the authority to issue opinions on acceptable accounting practice. To date the Board has issued six opinions. It was the second of these six opinions, issued in December I962, that heightened the current controversy.

APB Opinion No. 2, Accounting for the "Investment Credit,"22 was supported by fourteen members of the Accounting Principles Board; the Board is composed of twenty-one members, and a two-thirds majority (i.e., at least fourteen) is required for the issuance of an opinion. Opinion No. 2 recognized only one method of accounting for the investment credit, while several members of the Board felt strongly that at least one other method was equally correct, based on accepted practice, as the one approved by the Board. The requirement that everyone, except regulated companies, adopt the specified method or justify departures from it ignited the debate. The issues were seemingly clear-cut: Does the Accounting Principles Board have the right to limit the practice of accounting to one procedure? Is the profession to have uniform or flexible rules? ? $^{23}$

\section{Attempts to Obtain Agreement on Fundamentals}

One method of achieving a degree of uniformity would be to seek agreement on fundamental accounting concepts-postulates and principles, as they have come to be called by most-and it appeared for a time that the APB might be following this. path to the desired goal. Professor Herbert E. Miller, speaking before the Ig6I Annual Meeting of the Texas Society of CPAs, was optimistic about the acceptance of a set of broad accounting principles that were subsequently to be published as Accounting Research Studies Nos. I and 3. He expressed the opinion that "probably most accountants would say that research in the area of accounting principles was desirable in order to minimize any risk of loss of public confidence in financial statements." ${ }^{24}$ And it is clear that he was using the term principles in the broad sense. He continued with this observation:

\footnotetext{
${ }^{31}$ Spectal Comm. on Research Program, Report to Councti (1958), reprinted in J. Accountancy, Dec. 1958 , pp. $62-63$.

${ }^{2}$ Accounting Principles Board, AiCPA, Accounting for the "Investakent Credit" (Opinion No. 2, I962).

${ }^{23}$ Opinion No. 2 was subsequently amended by Accounting Princtples Board, AICPA, Accounting FOR THE "INVESTMENT CREDIT" (Opinion No. 4, I964), to permit alternative treatment of the investment credit.

s4 Miller, After There Is Agreement on Broad Accounting Principles-What Then?, Texas CPA, Sept. Ig6r, p. 3 .
} 
There is some room for doubt, however, as to whether agreement about principles will remove the risk of loss of public confidence in the accounting process. Such doubt is based on a belief that a good share of the present-day variations appearing in financial statements may not be attributable so much to any sad state of accounting principles as it is to the existence of a variety of methods or ways in which accountants apply their principles. ${ }^{25}$

He then raised the crucial question:

But how can this goal of achieving reasonable uniformity and comparability of accounting information be attained if we first of all permit the existence of a number of alternative ways to apply accounting principles and then go a step farther and label all alternative ways of applying principles as being equally acceptable? ${ }^{20}$

As we now know, the principles set forth in Accounting Research Studies Nos. I and $3^{27}$ have not been accepted by the profession nor has any other set of principles been accepted. Instead, members of the profession seem to have moved on to the alternative method of achieving uniformity suggested by Professor Miller-discussion of the desirability of eliminating alternative ways of applying principles. ${ }^{28}$ As indicated earlier, this very point was at issue in $193^{2}$ in the discussions between George $O$. May and M. C. Rorty. At that juncture reliance was placed on consistent application of principles over time. There is some evidence, as in the case of Swift \& Co. cited earlier, that even now accounting principles are not always applied consistently even though the auditor's opinion indicates that they have been. Ought consistency to remain the primary goal or has the profession of accountancy reached the stage where progress toward comparability can be made?

\section{III}

\section{The Current Debate}

In order to gain some flavor of the debate, which has reached a higher pitch in the last few years, let us examine some of the arguments.

Thomas G. Higgins has stated the crux of the problem as follows:

$[W]$ hen we independent public accountants report that financial statements are presented in conformity with "generally accepted accounting principles," we cannot be sure what we mean, because the expression "generally accepted accounting principles" has never been satisfactorily defined. ... [T] hose who issue the financial

${ }^{25} I d$. at 4 .

${ }^{26}$ Ibid.

${ }^{27}$ Maurice Moontz, The Basic Postulates of Accounting (AICPA Accounting Research Study No. I, 196r); Robert T. Sprouse \& Matrice Moonitz, A Tentative Set of Broad Accounting Prun. CIPLES FOR BUSINESS ENTERPRISEs (AICPA Accounting Research Study No. 3, 1962). Summaries of the postulates and principles arrived at in these studies are set forth in Appendices $A$ and $B$ at the end of this symposium.

${ }^{28}$ For a full development of this history, see Sprouse \& Vagts, The Accounting Principles Board and Differences and Inconsistencies in Accounting Practice: An Interim Appraisal, infra, pp. 706-26. 
statements on which we report, and those who use them, do not know what we mean, either. ${ }^{20}$

Mr. Higgins believes that the APB is the group with the authority to define accounting principles. However, there is a difference of opinion among the members of the Board about how to proceed in this matter. Mr. Higgins finds that some

Board members seriously question whether uniformity in accounting and comparability in financial reporting are desirable objectives. They feel that complete uniformity in accounting treatments and strict comparability of financial statements cannot be accomplished. Hence, they do not believe that the accounting profession, acting through the Accounting Principles Board, should move vigorously toward uniformity and comparability. They base their position in large part on the view that the responsibility of the directors of a corporation to account to stockholders through the medium of financial statements carries with it the authority to select the accounting methods to be followed by the corporation. ${ }^{30}$

Mr. Higgins finds this position contradictory. In his opinion, "defining the limitsproviding the criteria for determining the accounting methods to be used-is . . . the proper function of independent public accountants."31

Hassel Tippit, speaking on the same occasion, propounded a contrary point of view. In his opinion,

many people in our profession are groping for a panacea which would give them an immediate answer to any accounting problem. We have some in the profession who feel that alternative treatments should be eliminated on the theory that the gap in determining net income should be narrowed. Some people even go so far as to say that alternatives should be eliminated not because they are improper but because they contribute to undesirable flexibility.

It is extremely bothersome to me that many people in our profession are striving for such a rigidity of treatment which, if accepted, would eliminate all the professional judgment we feel are necessary in today's financial reporting. . . . I am convinced that one inflexible set of rules could not deal adequately with the various business philosophies that are encountered in the complex financial world of today. ${ }^{32}$

Mr. Tippit continued with his argument by indicating his concept of uniformity:

[I]t would be a tragic error for us to regiment accounting so that the answer to any question could be resolved quickly merely by turning to a given page in a book of rules and postulates.

Isn't a profession by its very nature dependent upon the sound and reasoned judgments of its members rather than upon a restrictive codification of do's and don'ts? By making more rules and regulations, are we increasing or decreasing our professional status?

\footnotetext{
${ }^{30}$ Higgins, The Accounting Principles Board and Uniformity in Financial Accounting, in TwENTYFiftu Annual Instrtute on Accounting, Proceenings 67, 7 I (Ohio State University, ig63).

${ }^{30} \mathrm{Id}$. at 72.

${ }^{31}$ Ibid.

${ }^{32}$ Tippit, Are We Expected to Eliminate All Alternatives?, in id. at 77,78 .
} 
As you so well know, under present-day accounting there are numerous alternative treatments which are considered to be acceptable....

....

... [I]t seems to me to be ridiculous for the profession to say that, after all these years, we will now determine the one way to handle each of these items and insist on full compliance, with all the alternatives bundled up into a package and tossed out the window.

In many of the areas, any alternative selected-if consistently followed-will produce the same result in the aggregate over a period of years. This, to me, is the big reason for including the reference to consistency in our present form of certificate. If all the alternatives are eliminated, I assume there will be no need for the word "consistency" in our certifications."

At the AICPA's annual meeting in Ig60 a session was devoted to discussion of the controversy. This discussion highlighted many of the complexities of the current debate. On this occasion, Maurice E. Peloubet seemed to stress throughout his paper that the basic principles should be uniform but that the rules of implementation must of necessity be flexible to allow for different treatment of different factual situations. For example, with respect to the proposition that "the areas of difference in accounting must be narrowed," he stated, "This is a desirable end, provided that all we are proposing is that differences in accounting methods be narrowed. There is always, however, a tendency to describe different things or conditions in the same terms merely to be uniform."34

Leonard Spacek argued on the same occasion that accountants' principles are not accepted by the public or corporate stockholders but are merely tolerated. He appeared to use the term principles to refer to the detailed rules guiding the accountant in his work, which is somewhat different from the use made of the word by Mr. Peloubet. Mr. Spacek argued that accounting principles must be fair and that this fairness must be demonstrated. He implied that uniform principles (using his meaning of the word) are more likely to produce fair accounts than is flexibility. In discussing this idea, he stated,

The objection has also been voiced that uniformity would eliminate flexibility in accounting principles. But to my knowledge, not one person has attempted to show where flexibility in the choice of alternative principles of accounting would result in financial statements that were fair to all segments of the business community. The arguments were only that flexibility was good, per se, and that the elimination of flexibility was bad, per se. Yet with respect to no single set of facts to be accounted for was the theory of Alexibility applied and reasoning advanced to show why the "flexible" results were proper or fair.

Assuming for the moment that flexibility of principles is needed for a transition period to permit improvement in accepted accounting principles, would not the proof of this contention demonstrate its merit by eventual elimination of the less de-

\footnotetext{
${ }^{83}$ Id. at 78-79.

${ }^{34}$ Peloubet, Is Further Uniformity Desirable or Possible?, J. Accountancy, April rg6r, p. 35, at 37.
} 
sirable practices? . . . Yet examination of the record shows that the alternative methods of accounting for intangible drilling costs . . . are each as old as the other. The alternative treatment of deferred income taxes is as old as the laws that permitted deferral of the taxes. The alternative treatment of pension costs is as old as the requirement that pensions be paid. Flexibility, as such, has not brought improvement; in fact, the less desirable practices have tended to drive out, or at least to retard, acceptance of the good. ${ }^{35}$

Professor Charles J. Gaa, in commenting on the papers presented by Messrs. Peloubet and Spacek, recognized the widely divergent meanings assigned to many of the words that are commonly found in the arguments about accounting problems and made a plea for standardization of terminology. He then turned his attention to the conflict between the speakers. He opined that "accounting 'principles' should be uniform for all profit-seeking enterprises, although there may have to be some allowable variations in detailed rules or practices. How to keep variations to an absolute minimum is the difficulty."36 $\mathrm{He}$ continued,

We should make every effort to achieve uniformity .... The closer we get to the bedrock of theory and the more general and fundamental we make our statements of "principles," the less likely they are to need change. As we get further out from this hard core into the area of detailed procedures, we are in the area of working rules which may need more frequent adjustment. Theory should not be used as a straitjacket, but instead as a core of logic, deviation from which must be justified convincingly and not by mere "nose-counting."

...

If we are to change our rules to reflect different factual situations, we must be careful to explore all ramifications of the factual change and alter in a sound and consistent manner all of the rules affected. If we come to the conclusion that inflation and a general price increase is a factual change which justifies an alteration in our depreciation rules or methods, we should not stop there just because this one change satisfies our immediate desires to show less income, to encourage management to replace assets because they are depreciated on the books, or to reduce income taxes. Our reflection of the factual change, inflation, must be stated more broadly, perhaps as a "principle" plus a set of related rules only one of which applies to depreciation. ${ }^{37}$

Carman G. Blough, as chairman of the session, commented in his summary as follows:

While I strongly subscribe to the idea that there should be a much greater narrowing of these areas of difference than has been possible to date, it seems to me it is, of necessity, a matter of evolution. Mr. Spacek hopes, along with most of the rest of us, that Congress will never lay down the principles that have to be followed. Yet, short of action by Congress or by some authority having absolute jurisdiction over all issuers of financial statements, the development of a comprehensive state-

\footnotetext{
${ }^{35}$ Spacek, Are Accounting Principles Generally Accepted?, J. Accountancy, April I96I, p. 4I, at 43.

${ }^{30}$ Gaa, Uniformity in Accounting "Principles," J. Accountancy, April x96r, p. 47, at 50.

${ }^{37}$ Id. at 50-5I.
} 
ment of accounting principles which will be universally accepted must be a long drawn out process. If we are ever to reach a point where the criteria are so well developed for any kind of transaction and so clear that they will always produce the same results when the situations are in fact identical, which Mr. Spacek feels is essential, and yet sufficiently flexible to meet differing situations, which $\mathrm{Mr}$. Peloubet thinks necessary, there will have to be a great deal of give and take with earnest, honest, intelligent effort over a long period of time. A certain amount of impatience can be a useful spur but too much can lead to disaster. ${ }^{38}$

Herman W. Bevis, a staunch supporter of flexibility in the application of accounting prinicples and one who is often referred to as the leader of the opposition or the "laissez-faire" group, has taken a rather strong position that regulation of the accounting profession, either by the profession itself or by government through prescription of accounting practice, is bad. Mr. Bevis comments, "Some critics seem to feel that the CPA of the future will be lost if the APB or some other body does not: ( $\mathrm{I}$ ) do his thinking for him-e.g., give him a detailed check list of the accounting practices, methods and treatments which he must see that his client follows; and (2) threaten to penalize him if he does not take exception in his opinion when the check list is not followed." ${ }^{39}$ He continues by adding the following admonition:

Remember that the number one objective is that the financial statements themselves communicate the desired information, and that the use of certificates to convey information is not only second-best but often confusing to the reader as well. Therefore, the effectiveness of the important economic function of communication of data from the issuer of financial statements to users is now involved; no move that diminishes that effectiveness will long be tolerated. ... [T] remain his own. It is personal and its value ... has to depend ... upon the CPA's oun competence and independence. ${ }^{40}$

Discussing generally accepted accounting principles, Mr. Bevis states: "In my opinion, there is a coherent and cohesive body of concepts behind present-day financial reporting, which not only gives meaning to the term 'generally accepted accounting principles' but is also the logic behind most (but not all) of the accounting treatments which are widely followed today by publicly owned corporations."

Mr. Bevis also has some very definite ideas about the manner in which the areas of difference should be narrowed. He is opposed to any plan of uniformity for the sake of uniformity and would like to allow for the individual differences that exist between companies or industries.

As to what the APB should do to narrow the areas of difference among significant accounting methods, my own view is that the most promising approach is industry by industry. ... In the industry approach, and notwithstanding the sig-

\footnotetext{
${ }^{38}$ Blough, Principles and Procedures, J. Accountancy, April 196r, p. 51, at 52.

${ }^{39}$ Bevis, How to Improve Financial Reporting, The Price Waterhouse Review, Autumn 1963, p. 4, at 6 .

${ }^{10} \mathrm{Yd}$. at $6-7$.

${ }^{41}$ Id. at $7-8$.
} 
nificant differences in operations among companies in any given group, there are two distinct advantages. First, the principal accounting problems and methods can be visualized in far more practical terms than for the economy as a whole. Second, an industry approach makes more feasible arousing the interest and enlisting the assistance of industry management and accountants in analyzing problems. Constant pressure for the elimination of marginal or small minority practices would give rcal meaning to the phrase "narrowing the areas of difference." 42

Mr. Bevis suggests that a part of the misunderstanding over the controversy about uniformity and flexibility is attributable to a misconception about what is meant by "greater comparability." He argues that

the term is comparative, and suggests moving in a direction; but moving in the direction of the rainbow is quite different from grasping at the end of it the pot of gold that is absolute comparability. All this suggests that the APB through the Institute has a public enlightenment job to do, in terms of educating all concerned that it has not discovered that which has up to now eluded all mankind-the means of satisfying the natural human craving for certainty. ${ }^{43}$

Finally, W. T. Baxter, of the London School of Economics, has offered a slightly different view on the question of uniformity:

Uniformity in presentation of published data ... has strong arguments in its favour-provided it neither cramps honest business nor begs ideas. If a choice between words or methods clearly is arbitrary and free from any pretence of research, it is not likely to damage future thinking or to act as a straitjacket .... Therefore, when we are attracted by uniformity, a good test is perhaps this: if a decision between possible terms or practices can be reached by tossing a coin or pulling words from a hat, then uniformity is unlikely to do harm.

... . Rules for standard practice should not prescribe valuation methods. Even rules on how items should be grouped in a balance-sheet may impinge on principle....

Perhaps "standard" should here mean "usual," i.e., what is normal but not necessarily right. ... An accountant should always reserve his right to depart from the standard, on giving notice, if he thinks the standard does not fit the particular case, or the reader's current needs, or his own views on theory. ${ }^{44}$

From the review of the arguments we can observe that the parties to the debate are often not debating the same issue. One is arguing that underlying principles are adequate guidelines, and another insists on a set of rules or regulations to which all must conform. The debate has been practically devoid of any discussion of what the underlying principles are or what specific rules should be adopted. Much of the debate has been emotional with little attempt to reason logically. The very

\footnotetext{
${ }^{12} I d$. at 8 .

${ }^{4} \mathrm{Ibid}$.

" Baxter, Recommendations on Accounting Theory, in Financiar Accounting Theory 427, 435-36 (Zeff \& Keller ed. I964).
} 
mention of the words uniformity and flexibility will incite most accountants to do verbal battle. The battlelines are drawn and the slogan "I'd rather fight than switch" has become the byword. The great need at the present time is for operational principles or guidelines and methods by which to implement them.

\section{IV}

\section{Summary and Conclusions}

There is very little common ground shared by the two sides. The disagreement involves the foundation on which accounting practice is built, and several accountants have charged that there is no solid foundation and no common ground upon which rebuilding can begin. In many instances the terminology causes disagreement because there are no accepted definitions of key words.

Then there is the crucial question of what really should be uniform-guides and concepts, or methods and applications? Is it more important that financial statements reflect economic activity or the application of specific rules to the classification of data without regard to differences in facts and circumstances? What function should financial statements, prepared for the use of the investing public, serve? Are they a report on past activity or a prediction of the future? These are questions to which there are no definite answers, but they are questions that need to be resolved before accountants can really begin meaningfully to debate the ultimate issue.

If the accounting profession will stop and take stock of the basic concepts underlying economic activity and recognize that this activity must be measured quantitatively to enable comparisons to be made, I am confident that the current conflict will be settled amicably and with a substantial improvement in the informational content of financial reports. There will probably never be strict rules requiring that all inventory be valued according to one standard procedure. On the other hand, there are quite likely to be standards that require the accountant to select a method for valuing inventory that is based on specified concepts and that reflects the peculiarities of the particular situation. No one procedure is likely to be prescribed as the right procedure.

When the emotion that now pervades the argument loses some of its intensity and when the debaters cease to use terms like compliance, conformity, and regulation and others implying limited use of judgment (perhaps including even uniformity itself), then the parties are likely to begin to develop a set of workable guidelines. The accounting profession will emerge unified and stronger, the public will have financial reports that more accurately reflect the results of past activity, and the freedom to exercise professional judgment will not have been impaired. In fact, the greater acceptance of common concepts will provide the profession with a frame of reference within which the individual accountant can more effectively exercise his professional judgment. The accountant will be able, and indeed required, to give 
reasons for selecting a given procedure and will not be able to hide behind empty phrases or the assertion of management's primary responsibility for the choice of methods. Undoubtedly, some quasi-judicial body will in time emerge to resolve situations in which the judgment of the accountant is questioned.

The time required to solve the existing problems will be long even if the task is begun in earnest today. Additional time to reach a consensus on the nature of the task may not be available. How long will the public and its watchdog, the SEC, give the accounting profession to accomplish the job? 